\title{
Hypereosinophilic Syndrome: Hacettepe Experience
}

\author{
Betul Tavil, MD, Selin Aytaç, MD, Sule Unal, MD, Baris Kuskonmaz, MD, \\ Fatma Gumruk, MD, and Mualla Cetin, MD
}

\begin{abstract}
Summary: The aim was to evaluate baseline demographic, clinical, and laboratory characteristics, treatment modalities, and outcome of children with idiopathic hypereosinophilic syndrome (HES) followed up in our center. Children who fulfilled the criteria of idiopathic HES followed up at Hacettepe University Faculty of Medicine, Pediatric Hematology Department between June 2004 and October 2013 were included in this study. Medical records of all children with idiopathic HES were reviewed to obtain regarding data. The mean age of 6 children with idiopathic HES was $52.8 \pm 44.3$ months ( 13 to $132 \mathrm{mo}$ ) at diagnosis. Among 6 children with idiopathic HES; 2 had pulmonary involvement; 1 had cardiac and pulmonary involvement and splenomegaly; 1 had cardiac involvement and hepatosplenomegaly; 1 had cardiac and central nervous system involvement; and 1 had skin involvement. The mean follow-up duration was $36.5 \pm 31.4$ months. Methyl prednisolone (MP) was used for the first-line therapy. Complete response was achieved with MP in 3 children. All steroid responsive children are alive; whereas 3 children who did not respond to MP had expired. In conclusion, cardiac and pulmonary involvement is the major causes of mortality in HES. Resistance to steroid therapy indicates poor prognosis.
\end{abstract}

Key Words: idiopathic hypereosinophilic syndrome, methyl prednisolone, children

(J Pediatr Hematol Oncol 2016;38:539-543)

$T^{\mathrm{h}}$ he upper limit of normal range of eosinophil count is $500 / \mathrm{mm}^{3}$. The severity of eosinophilia has been categorized into mild (absolute eosinophil count [AEC] from the upper limit of normal to $1500 / \mathrm{mm}^{3}$ ), moderate (AEC, 1500 to $5000 / \mathrm{mm}^{3}$ ), and severe $\left(\mathrm{AEC}>5000 / \mathrm{mm}^{3}\right)$. The most common worldwide cause of eosinophilia is parasitic infections and the most common cause is atopic diseases in industrialized countries. In the absence of an identifiable cause of moderate to severe eosinophilia and in the presence of end-organ involvement; the diagnosis of the idiopathic hypereosinophilic syndrome (HES) should be considered. ${ }^{1-4}$ The criteria for idiopathic HES include marked peripheral blood eosinophilia $\left(>1500 / \mathrm{mm}^{3}\right)$ recorded on at least 2 occasions with a minimum time interval of 4 weeks and organ damage and/or dysfunction attributable to tissue hypereosinophilia and exclusion of other disorders or conditions as major reason for organ damage. ${ }^{5}$ The exact prevalence of the disease is unknown. Idiopathic HES occurs most frequently in middle-aged patients. Male

Received for publication March 11, 2016; accepted July 21, 2016.

From the Hacettepe University Faculty of Medicine, Ihsan Dogramaci Children's Hospital, Pediatric Hematology Unit, Sihhiye, Ankara, Turkey.

The authors declare no conflict of interest.

Reprints: Betul Tavil, MD, Hacettepe University Faculty of Medicine,

Ihsan Dogramaci Children's Hospital, Pediatric Hematology Unit,

Sihhiye, Ankara 06100, Turkey (e-mail: tavil@ hacettepe.edu.tr).

Copyright (C) 2016 Wolters Kluwer Health, Inc. All rights reserved. predominance (4 to 9:1 ratio) has been reported in historic series, but this is likely to reflect the male distribution of chromosomal deletion on 4q12 leading to the Fib1-Like1Platelet derived growth factor receptor alpha (FIP1L1PDGFRA) fusion gene found in a recently characterized disease variant $(\mathrm{F} / \mathrm{P}+$ variant $)$. Pediatric HES has only a slight male predominance $\left(55.3 \%\right.$ boys vs. $44.7 \%$ girls). ${ }^{6,7}$ In children, idiopathic HES is rare and there has been only limited number of small case series in English literature. Because of lack of systematic registration of pediatric HES, the true incidence is unknown and only scarce data are available on treatment, response, and survival of children with idiopathic HES. ${ }^{8-11}$

In this study, we decided to evaluate baseline demographic, clinical, and laboratory characteristics, treatment modalities, and outcome of children with idiopathic HES followed up in our center.

\section{MATERIALS AND METHODS}

Children who fulfilled the criteria of idiopathic HES followed up at Hacettepe University Faculty of Medicine, Pediatric Hematology Department between June 2004 and October 2013 were included in this study. HES was defined by the following criteria: (a) peripheral blood eosinophilia of $>1500 / \mathrm{mm}^{3}$ on at least 2 occasions and/or tissue hypereosinophilia; (b) organ damage and/or dysfunction attributable to tissue hypereosinophilia and; (c) exclusion of other disorders or conditions as major reason for organ damage. Tissue hypereosinophilia is defined by the following criteria: (1) Percentage of eosinophils in bone marrow section exceeds $20 \%$ of all nucleated cells and/or (2) Tissue infiltration by eosinophils is extensive reported by pathologist and/or (3) Marked deposition of eosinophil granule proteins is found in the absence or presence of major tissue infiltration by eosinophils. ${ }^{5}$ The diagnostic criteria for idiopathic HES also requires ruling out primary (clonal) hypereosinophilia by appropriate cytogenetic and molecular studies to look for deletion $4 \mathrm{q} 12$ (Fib1-Like1Platelet derived growth factor receptor alpha) and other rearrangements. According to the defined criteria, a total of 6 children among 9 with hypereosinophilia followed up in our center in this time period were identified as having idiopathic HES. Medical records of all children with idiopathic HES were reviewed to obtain data regarding demographics, clinical presentation, imaging and laboratory studies, comorbidities, diagnostic testing, treatment modalities, clinical course, and outcome. Bone marrow aspiration was performed for all children with idiopathic HES to exclude leukemia and perform cytogenetic studies. Cardiac involvement was documented by echocardiography. Central nervous system (CNS) involvement was diagnosed by cranial magnetic resonance imaging. Pulmonary involvement was documented by thorax computed tomography (CT). Bronchoalveolar lavage (BAL) was 
performed when thorax CT findings suggested pulmonary involvement. In BAL fluid, eosinophilia $\geq 25 \%$ was considered as significant. "Flare" was defined as reappearance of eosinophils in peripheral blood and bone marrow and arising clinical findings related to organ involvement. The response to treatment was evaluated for each of the child after 1 month of treatment. Clinical responses at 1 month of treatment were recorded as complete, partial, or no response. Complete response was defined as decrease of the eosinophil count to the normal range $\left(0\right.$ to $\left.500 / \mathrm{mm}^{3}\right)$ and symptomatic improvement after 1 month of treatment. Partial response was defined as a decrease of the eosinophil count, but not to the normal range, and/or symptomatic improvement after 1 month of treatment. No response was defined as a stable or increasing eosinophil count and no symptomatic improvement after 1 month of treatment. Follow-up period was defined as the interval from the time of diagnosis to the date of the last available medical evaluation documented in the medical records.

SPSS for Windows version 18.0 (SPSS Inc., Chicago, IL) was used for evaluation of the data.

\section{RESULTS}

\section{Baseline Characteristics}

The median age of 6 children ( 4 girls and 2 boys) with idiopathic HES was 40 months (range, 13 to $132 \mathrm{mo}$ ) at diagnosis. Specifically; none of the children exhibited secondary causes of eosinophilia. Lymphocyte subset analysis, immunoglobulin levels, serological studies for acute viral infections, and vitamin B12 levels were within normal range for these children. The main clinical and laboratory features at the time of presentation, treatment modalities and response to treatment, follow-up duration, and outcome of the children with idiopathic HES have been summarized in Table 1.

The most common complaints at admission were malaise, fever, headache, cough, dyspnea, and pain in the extremities. Other less common complaints were poor appetite, nausea, dizziness, abdominal pain, itches, and perioral cyanosis. On physical examination, common findings were rales and crackles on auscultation, hepatosplenomegaly, splenomegaly, rash on extremities, and perioral cyanosis (Table 1).

At diagnosis, the mean eosinophils count was $38000 \pm 37000 / \mathrm{mm}^{3}$ (3500 to $\left.109000 / \mathrm{mm}^{3}\right)$. The mean percentage of eosinophils in peripheral blood smear was $41.5 \pm 30.5 \%$ (range, $7 \%$ to $80 \%$ ). Two children had thrombocytosis at diagnosis. Their platelet counts returned to normal after steroid treatment.

Bone marrow aspiration smears of the children showed increased rate of eosinophil precursors and eosinophils. The mean rate of eosinophilia was $32.7 \pm 18.6 \%$ (11 to $56 \%$ ) in bone marrow aspiration smears at diagnosis.

Among 6 children with diagnosis of HES; 2 had isolated pulmonary involvement; 1 had cardiac and pulmonary involvement and splenomegaly; 1 had cardiac involvement and hepatosplenomegaly; 1 had cardiac and CNS involvement; and 1 had skin involvement at diagnosis. Of these 3 children with pulmonary involvement; thorax CT revealed peripheral pulmonary nodules and ground glass opacities in 2 children (case no. 1 and 6) and only peripheral pulmonary nodules in 1 child (case no. 2). All 3 children had eosinophils in BAL fluid. Among 3 children with cardiac involvement; echocardiography showed thrombus in both ventricles in 1 child; mitral valvular insufficiency in 1 child; and papillary muscle hypertrophy, thickening of the posterior wall, and apical thrombus in both ventricles in another child. Cranial magnetic resonance showed cerebral ischemic lesions in bilateral basal ganglia, thalamus, left cerebellar vermis, and cerebral parenchyma in 1 child with CNS involvement.

All children had a normal karyotype except case no. 1 who had trisomy 7 in $2 / 20$ nucleus studied by fluorescence in situ hybridization at diagnosis. This cytogenetic abnormality was not detected in her other bone marrow aspiration samples. FIP1LI-PDGFRA fusion gene studied in 3 children was negative. Flow cytometric analysis of bone marrow showed no T-cell clonality for all children.

\section{Treatment and Outcome}

Methyl prednisolone (MP) at a dosage of $2 \mathrm{mg} / \mathrm{kg} /$ day was chosen for the first-line therapy for all children. Complete response was achieved with monotherapy of MP in 3 children. Monotherapy of MP was used for 3 months in 2 children and for 6 months in 1 child. Apart from conventional doses; high dose MP (HDMP) treatment was used for case no. 1, 2, and 4. If a child did not respond to MP; MP dosage decreased and tapered slowly. Furthermore, the minimum dosage of MP was used to keep the patient in remission between flares. We did not see any serious side effects of MP except cushingoid appearance in this case series. All steroid responsive children $(n=3,50 \%)$ are in good health and have still been followed up in our center for a median follow-up duration of 24 months (range, 3 to $108 \mathrm{mo}$ ). Unfortunately, 3 children (case no. 1, 2, and 4) who did not respond to MP had expired.

In our case series; 1 child had 6 flares, 3 children had 2 flares, and 2 children had 1 flare of HES. Case no. 1 had 6 flares during 65 months of follow-up duration. Unfortunately, she had no HLA match related or unrelated donor and she expired at her sixth flares due to multiorgan failure. Pulmonary fibrosis and tissue damage with eosinophilia were observed in her autopsy.

Neither child responded to any treatments. Hydroxyurea, interferon- $\alpha$ (IF- $\alpha)$, vincristine, and cyclophosphamide treatments were used for case no. 1. Vincristine and cyclophosphamide were used for case no. 2. Case no. 2 had expired at his second flare due to multiorgan failure. The search for an HLA-matched donor was underway when he expired. The third case expired; case no. 4 had severe cardiac and CNS involvement at initial presentation. He was steroid resistant on his first flare. He did not respond to other treatments including hydroxyurea, vincristine, and imatinib mesylate. Thus, he had hematopoietic stem cell transplantation (HSCT) from his HLA identical brother 7 months after his first presentation. Neutrophil and platelet engraftments were achieved, but he expired due to acute graft versus host disease and venoocclusive disease during the first 100 day after HSCT.

\section{DISCUSSION}

Presentation of idiopathic HES is heterogeneous, varying from a number of nonspecific complaints such as fatigue, cough, rhinitis, dyspnea, itching, skin rash, to life threatening cardiac, or neurologic events. ${ }^{3}$ Katz et $\mathrm{al}^{8}$ reported 38 pediatric HES cases based on literature review. In these pediatric cases; fever (58.8\%), arthralgias (23.5\%), and rash $(23.5 \%)$ were common presentation symptoms. 
TABLE 1. The Main Clinical and Laboratory Features of Children With Idiopathic Hypereosinophilic Syndrome

\begin{tabular}{|c|c|c|c|c|c|c|c|c|c|c|c|c|c|}
\hline $\begin{array}{l}\text { Case } \\
\text { Number }\end{array}$ & Age/Sex & $\begin{array}{c}\text { Complaints at } \\
\text { Admission }\end{array}$ & $\begin{array}{l}\text { Physical } \\
\text { Examination } \\
\text { Findings on } \\
\text { Admission } \\
\end{array}$ & $\begin{array}{c}\text { Total } \\
\text { Leukocyte } \\
\text { Count } \\
\left(\times 10^{9} / \mathrm{L}\right) \\
\end{array}$ & $\begin{array}{c}\text { Eosinophils } \\
(\%)\end{array}$ & $\begin{array}{c}\text { Absolute } \\
\text { Eosinophil } \\
\text { Count } \\
\left(\times 10^{9} / \mathrm{L}\right) \\
\end{array}$ & $\begin{array}{c}\text { BM } \\
\text { Eosinophils } \\
(\%) \\
\end{array}$ & $\begin{array}{c}\text { IgE } \\
\text { Level } \\
(\mathrm{U} / \mathrm{L}) \\
\end{array}$ & $\begin{array}{c}\text { Organ Involvement at } \\
\text { Diagnosis }\end{array}$ & $\begin{array}{l}\text { The No. } \\
\text { Recurrence }\end{array}$ & Treatment & $\begin{array}{l}\text { Follow- } \\
\text { Up } \\
\text { Duration } \\
\text { (mo) }\end{array}$ & Outcomes \\
\hline 1 & $13 \mathrm{mo} /$ girl & $\begin{array}{l}\text { Cough, } \\
\text { dyspnea, } \\
\text { cyanosis }\end{array}$ & $\begin{array}{l}\text { Peroral cyanosis, } \\
\text { rales, crackles on } \\
\text { auscultation }\end{array}$ & 44.5 & 48 & 21.2 & 28 & 1.2 & $\begin{array}{l}\text { Pulmonary involvement } \\
\text { Thorax CT: small peripheral } \\
\text { pulmonary nodules and } \\
\text { ground glass opacities }\end{array}$ & 6 & $\begin{array}{l}\text { MP, hydroxyurea, } \\
\text { IF- } \alpha \text {, vincristine, } \\
\text { cyclophosphamide }\end{array}$ & 65 & $\begin{array}{l}\text { Expired } \\
\text { due to } \\
\text { multior- } \\
\text { gan } \\
\text { failure } \\
\text { At sixth } \\
\text { attack }\end{array}$ \\
\hline 2 & $11 \mathrm{y} /$ boy & $\begin{array}{l}\text { Fever, cough, } \\
\text { malaise, leg } \\
\text { pain }\end{array}$ & Splenomegaly & 135 & 80 & 109 & 36 & 12.2 & $\begin{array}{l}\text { Cardiac involvement } \\
\text { Pulmonary involvement } \\
\text { ECHO: thrombus in both } \\
\text { ventricles } \\
\text { Thorax CT: small peripheral } \\
\text { pulmonary nodules }\end{array}$ & 2 & $\begin{array}{l}\text { MP, vincristine, } \\
\text { cyclophosphamide }\end{array}$ & 6 & $\begin{array}{l}\text { Expired } \\
\text { due to } \\
\text { multior- } \\
\text { gan } \\
\text { failure } \\
\text { At second } \\
\text { attack }\end{array}$ \\
\hline 3 & $20 \mathrm{mo} / \mathrm{girl}$ & $\begin{array}{l}\text { Malaise, poor } \\
\text { appetite }\end{array}$ & Hepatosplenomegaly & 12 & 30 & 3.7 & 56 & 19.4 & $\begin{array}{l}\text { Cardiac involvement } \\
\text { ECHO: mitral } \\
\text { valvular insufficiency }\end{array}$ & 1 & MP (6 mo) & 24 & $\begin{array}{l}\text { Alive in } \\
\text { good } \\
\text { health }\end{array}$ \\
\hline 4 & $6 \mathrm{y} /$ boy & $\begin{array}{l}\text { Nausea, } \\
\text { headache, } \\
\text { dizziness, } \\
\text { pain in the } \\
\text { arms and legs }\end{array}$ & Normal & 118 & 72 & 85.4 & 24 & 更 & $\begin{array}{l}\text { Cardiac involvement } \\
\text { Central nervous system } \\
\text { imvolvement } \\
\text { ECHO/Cardiac MRI: } \\
\text { papillary muscle } \\
\text { hypertrophy, thickening } \\
\text { of the posterior wall, and } \\
\text { apical thrombus in both } \\
\text { ventricles } \\
\text { Cranial magnetic resonance: } \\
\text { cerebral ischemic lesions } \\
\text { in bilateral basal ganglia, } \\
\text { thalamus, left cerebellar } \\
\text { vermis and cerebral } \\
\text { parenchyma }\end{array}$ & 2 & $\begin{array}{l}\text { MP, hydroxyurea, } \\
\text { vincristine, } \\
\text { imatinib mesylate, } \\
\text { BMT }\end{array}$ & 10 & $\begin{array}{l}\text { Expired } \\
\text { due to } \\
\text { acute } \\
\text { GvHD } \\
\text { and } \\
\text { VOD } \\
\text { During the } \\
\text { first } \\
100 \mathrm{~d} \text { of } \\
\text { BMT } \\
\text { From his } \\
\text { HLA full } \\
\text { match } \\
\text { brother }\end{array}$ \\
\hline 5 & $2.5 \mathrm{y} /$ girl & $\begin{array}{l}\text { Fever, malaise, } \\
\text { headache, } \\
\text { abdominal } \\
\text { pain }\end{array}$ & $\begin{array}{l}\text { Rash and itch in her } \\
\text { hands and feet }\end{array}$ & 29.8 & 12 & 3.6 & 40 & 12 & Skin involvement & 2 & $\mathrm{MP}(3 \mathrm{mo})$ & 108 & $\begin{array}{l}\text { Alive in } \\
\text { good } \\
\text { health }\end{array}$ \\
\hline 6 & $4^{2 / 12} \mathrm{y} /$ girl & Fever, Dyspnea & $\begin{array}{l}\text { Rales and crackles } \\
\text { on auscultation }\end{array}$ & 17.5 & 7 & 6.8 & 22 & 14.1 & $\begin{array}{l}\text { Pulmonary involvement } \\
\text { Thorax CT: small peripheral } \\
\text { pulmonary nodules and } \\
\text { ground glass opacities }\end{array}$ & 1 & MP (3 mo) & 3 & $\begin{array}{l}\text { Alive in } \\
\text { good } \\
\text { health }\end{array}$ \\
\hline
\end{tabular}

BM indicates Bone marrow; BMT, bone marrow transplantation; CT, computerized tomography; ECHO, echocardiography; GvHD, graft versus host disease; IgE, Immunoglobulin E; MP, methylprednisolone; MRI, magnetic resonance imaging; VOD, venoocclusive disease. 
In our case series, 2 children had thrombocytosis. We thought that thrombocytosis was resulted from chronic inflammation and tissue damage in these children with idiopathic HES. Steroid treatment decreases eosinophilia and inflammatory response. ${ }^{12}$ This also caused a decrease in platelet count in these children with thrombocytosis. In English literature, thrombocytosis has been described in patients with chronic eosinophilic pneumonia. The patients' thrombocyte count returned to normal under steroid therapy as in our cases. ${ }^{13,14}$

Tissue infiltration by eosinophils and release of some cytokines and humoral factors from the eosinophilic granules leads to tissue damage in multiple organs involving skin, lungs, heart, and $\mathrm{CNS}^{3}$ In our patients group, pulmonary $(50 \%)$ and cardiac $(50 \%)$ involvements were the most common clinical manifestations of idiopathic HES. This was followed in frequency by skin $(16.6 \%)$ and CNS $(16.6 \%)$ involvements. In addition, 1 child had splenomegaly and 1 had hepatosplenomegaly. Katz et al ${ }^{8}$ reported that cardiac $(71.0 \%)$, pulmonary $(55.3 \%)$, and skin $(34.2 \%)$ involvements were the most common clinical manifestations in pediatric patients. In the largest adult series, Ogbogu et $\mathrm{al}^{15}$ reported that skin $(37.0 \%)$ involvement was the most common presenting manifestation; followed by pulmonary (25\%) and gastrointestinal (14\%) involvements. Cardiac and neurologic involvements were less observed clinical manifestations in adult patients with HES. As with adults, involvement of the cardiovascular system has been presented as the major source of morbidity and mortality in pediatric HES cases. In our patients group, 2 of 3 expired cases had cardiac and pulmonary involvement.

Therapeutic management should be adjusted according to the disease severity. The goal of therapy in patients with HES is to lower the eosinophil count and prevent organ dysfunction. Corticosteroids are potent antieosinophil agents with established efficacy in HES and should be considered as first-line treatment. HDMP is also a treatment alternative for patients with HES. The mechanism of action for corticosteroids in HES is not clear. Corticosteroids interfere with eosinophil production. Accelerated apoptosis and/or sequestration of eosinophils may also play a role in control of eosinophilia. ${ }^{16}$ For children unresponsive to steroids, agents such as hydroxyurea, IF- $\alpha$, vincristine, and mercaptopurine have been used. For $\mathrm{F} / \mathrm{P}+$ patients, imatinib has become first-line therapy. The FIP1L1-PDGFRA mutation on the fourth chromosome leads to a tyrosine kinase fusion protein. Thus, imatinib, a tyrosine kinase inhibitor is effective treatment option for $\mathrm{F} /$ $\mathrm{P}+$ patients. It has been reported that imatinib is more effective in $\mathrm{F} / \mathrm{P}+$ patients $(88 \%)$ than in $\mathrm{F} / \mathrm{P}-$ patients $(23 \%) .{ }^{15,16}$ For patients except $\mathrm{F} / \mathrm{P}+$ ones, corticosteroids should be used as first-line therapy. If a patient with HES is corticosteroid resistant; corticosteroid should be followed by hydroxyurea, IF- $\alpha$, other chemotherapeutic agents, and imatinib. Corticosteroids should be given concomitantly with imatinib in suspected cases of eosinophilic myocarditis to prevent myocardial necrosis; which is a rare complication of imatinib therapy in HES.

In the largest adult series of HES, corticosteroid monotherapy induced complete or partial responses in $85 \%$ of cases. ${ }^{15}$ In our series, $50 \%$ of children responded steroid therapy. Uçkan et al showed that HDMP had a suppressive role on eosinophil and lymphocyte activation in 2 siblings with marked hypereosinophilia in our center. ${ }^{17}$ In our case series, HDMP was used for 3 cases who did not responded to steroid treatment at a dosage of $2 \mathrm{mg} / \mathrm{kg} /$ day. In case no. 1; HDMP treatment was effective for improvement of her third, fourth, and fifth flares. However, she expired at her sixth flare despite HDMP and other treatment agents. In our series; steroid resistant 3 children did not respond any other treatments including hydroxyurea, IF- $\alpha$, vincristine, cyclophosphamide, and imatinib therapies at their last flares. These 3 steroid resistant children were very difficult cases and all had expired. We have known that imatinib is more effective in $\mathrm{F} / \mathrm{P}+$ patients, whereas this mutation was studied in our 3 cases and found to be negative. Although FIP1L1-PDGFRA mutation was negative, imatinib treatment was tried in case no. 4. Imatinib treatment at a dosage of $100 \mathrm{mg}$ /day was used until HSCT. However, he did not give any response to imatinib treatment.

Prognosis of HES currently depends on development of irreversible heart failure, as well as eventual malignant transformation of myeloid or lymphoid cells. The information about long-term prognosis of children with HES is very limited in English literature. In a patient series reported by Katz et al, ${ }^{8} 15$ of $36(41.6 \%)$ cases were alive at the time of these cases were published and the mean length of survival was 10.6 months (range, 0.2 to $42 \mathrm{mo}$ ) from the time of diagnosis. In our patients group, the mean followup duration was $36.5 \pm 31.5$ months (median, $17 \mathrm{mo}$; range, 6 to $108 \mathrm{mo})$. During this follow-up period, 3 (50\%) children were alive and have still been followed up in our center. Follow-up care is important for the survival of the patient, because hypereosinophilia flares may be observed during the disease course. One of our patients had 6 flares and 3 patients had 2 flares during the follow-up period. The first flare may be very severe as in our case no. 4 or the following flares may be more severe and lethal as in cases no. 1 and 2 .

In conclusion, cardiac and pulmonary involvement has been presented as the major cause of mortality in our group. Furthermore, steroid resistant cases had very poor prognosis and the disease course might be fatal. Although there is limited published literature in pediatrics, HSCT could be considered for such patients. ${ }^{18,19}$

\section{REFERENCES}

1. Gotlib J. World Health Organization-defined eosinophilic disorders: 2011 update on diagnosis, risk stratification, and management. Am J Hematol. 2011;86:678-688.

2. Rothenberg ME. Eosinophilia. New Engl J Med. 1998;338: 1592-1600.

3. Pardanani A, Patnaik MM, Tefferi A. Eosinophilia: secondary, clonal and idiopathic. Br J Haematol. 2006;133:468-492.

4. Simon HU, Rothenberg ME, Bochner BS, et al. Refining the definition of hypereosinophilic syndrome. $J$ Allergy Clin Immunol. 2010;126:45-49.

5. Valent P, Klion AD, Horny HP, et al. Contemporary consensus proposal on criteria and classification of eosinophilic disorders and related syndromes. J Allergy Clin Immunol. 2012;130:607-612.

6. Weller PF. The idiopathic hypereosinophilic syndrome. Blood. 1994;83:2759-2779.

7. Roufosse FE, Goldman M, Cogan E. Hypereosinophilic syndromes. Orphanet $J$ Rare Dis. 2007;2:37.

8. Katz HT, Haque SJ, Hsieh FH. Pediatric hypereosinophilic syndrome (HES) differs from adult HES. J Pediatr. 2005;146: 134-136.

9. Rapanotti MC, Caruso R, Ammatuna E, et al. Molecular characterization of paediatric idiopathic hypereosinophilia. $\mathrm{Br}$ J Haematol. 2010;151:440-446. 
10. van Grotel M, de Hoog M, de Krijger RR, et al. Hypereosinophilic syndrome in children. Leuk Res. 2012;36: $1249-1254$.

11. Kanthila J, Bhaskaranand N. Idiopathic hypereosinophilic syndrome in children: 3 cases with review of literature. Indian $J$ Pediatr. 2013;80:124-127.

12. Roufosse F, Weller PF. Practical approach to the patient with hypereosinophilia. J Allergy Clin Immunol. 2010;126: 39-44.

13. Brezis M, Lafair J. Thrombocytosis in chronic eosinophilic pneumonia. Chest. 1979;76:231-232.

14. d'Amours P, Leblanc P, Boulet LP. Chronic eosinophilic pneumonia associated with thrombocytosis and pleural effusion. CMAJ. 1990;142:837-839.

15. Ogbogu PU, Bochner BS, Butterfield JH, et al. Hypereosinophilic syndrome: a multicenter, retrospective analysis of clinical characteristics and response to therapy. $J$ Allergy Clin Immunol. 2009;124:1319-1325.

16. Gotlib J. World Health Organization-defined eosinophilic disorders: 2012 update on diagnosis, risk stratification, and management. Am J Hematol. 2012;87:903-914.

17. Uçkan D, Hiçsönmez G, Tunç B, et al. The analysis of eosinophil and lymphocyte phenotype following single dose of high-dose methylprednisolone in two siblings with marked hypereosinophilia. Clin Lab Haematol. 2001;23:33-37.

18. Halaburda K, Prejzner W, Szatkowski D, et al. Allogeneic bone marrow transplantation for hypereosinophilic syndrome: long-term follow-up with eradication of FIP1L1-PDGFRA fusion transcript. Bone Marrow Transplant. 2006;38:319-320.

19. Fukushima T, Kuriyama K, Ito $H$, et al. Successful bone marrow transplantation for idiopathic hypereosinophilic syndrome. Br J Haematol. 1995;90:213-215. 